\title{
FORUM
}

\section{Traffic Separation in the Dover Strait}

\section{A Report}

THE recent collisions in the English Channel and the Dover Strait have caused a great deal of public disquiet in this country and the United Kingdom's Department of Trade and Industry's Safety of Navigation Committee were invited to discuss what, if any, measures should be recommended to Imco to improve the routing system in the Strait. The Institute of Navigation, with its French and German counterparts, was largely responsible for the introduction of the routing scheme in force in the Strait and has since its introduction in 1967 , by means of a series of international working groups, kept a watchful eye on how things were going, and on occasions made recommendations for its improvement.

The recommendations of the Institute's successive international working groups or committees form the basis of the traffic separation schemes now in force throughout North-West Europe; they have also attempted surveys of the traffic pattern and the analysis of collision statistics in these areas. The unofficial character of these groups has enabled them to provide an international forum where matters can be discussed freely rather than from prepared positions, and as a result a great deal of attention is generally paid by Imco to what they say.

In the present circumstances the Council of the Institute thought it would be useful if the Institute's experience and authority in these matters could be placed at the disposal of those responsible for routing, both at government and intergovernmental level. Accordingly, they called together a Committee representative of the interests most closely involved in Dover Strait navigation to consider whether any improvements are called for in the system of routing in the Strait and to make any other recommendations they might see fit.

The Committee, whose membership is given below, met in London on 3 February 1971, with the President of the Institute in the Chair. Its recommendations, which are contained in the following report, were transmitted to the D.T.I.'s Safety of Navigation Committee at its meeting in London on 5 February. They are for the most part included in the U.K. government's subsequent submission to Imco on the subject.

\section{PRESEN'T}

Rear-Admiral G. S. Ritchie (Hydrographer of the Navy, President of the Institute of Navigation)

Captain J. Arthur (British Rail Cross-Channel Master)

J. H. Beattie (member Dover Strait Working Group)

Captain T. Dilling (Scandinavian Shipowners' Association)

Captain R. Hart (Nautical Adviser, British \& Commonwealth Shipping Company)

F. A. Haworth (Lloyd's)

Captain J. N. F. Lameijer (Royal Netherlands Shipowners' Association)

Captain A. C. Manson (Department of Trade and Industry)

Captain G. Marinet (Comité Central des Armateurs de France) 
Captain R. Maybourn (Chief Marine Superintendent, BP Tanker Company)

Commander R. G. Moore (U.S. Coast Guard)

Commandant L. Oudet (member Dover Strait Working Group)

H. M. Preece (Cinque Ports Pilot)

R. B. Richardson (Harbour Master, Port of London)

Captain Schumann (Deutsche Hydrographische Institute and D.G.O.N.)

Captain I. F. Somerville (Chamber of Shipping of the United Kingdom)

Captain W. Stecher (German Shipowners' Association)

Professor A. Stratton (Director of the Defence Operational Analysis Establishment)

Captain P. A. Thompson (Tanker Master)

Captain D. S. Tibbits (Elder Brother of Trinity House)

M. W. Richey, Executive Secretary of the Institute of Navigation

Observers (at the suggestion of Trinity House)

Captain O. Elsom

Captain N. Knowles

\section{RECOMMENDATIONS}

\section{Traffic and Collision Statistics}

Public disquiet, however understandable, is not of itself a reason for altering or extending traffic separation schemes and the meeting sought first of all to establish, on the basis of the most recent collision statistics available, what the present position was and what inferences might be drawn from the figures.

Broadly the indication was that the collision rate in the Dover Strait for the 44 months before and after routing was about constant, although the average collisions per fog day had been reduced. There was insufficient evidence to draw any statistically significant inference from these figures.

Seventy per cent of the collisions had occurred in the one-way traffic lanes and so far as could be seen 60 per cent of these involved meeting situations; however this latter conclusion was drawn simply from information as to ports of departure and destination, and could not necessarily be accepted without further investigation. The probability, however, is clearly that in the majority of these cases one ship was in the wrong lane.

No reliable information is available about the volume of traffic in the Strait, or about how it has changed over the years. The Committee felt that no intelligent interpretation of the collision statistics could be made on the information now available and that there was an urgent need for a complete traffic survey of the area professionally conducted as a piece of operational research. The causes of individual collisions needed to be investigated, including factors such as inadequate navigation equipment, human errors, \&c.

\section{Observance of the Routes}

The meeting considered a report of a survey conducted by the United Kingdom, French and Belgian authorities into the observance of the one-way routes in the Strait, from which it appeared that some 5 per cent of ships were still not observing the recommendations. There was no indication in the survey that 
draught had any influence on observance. The figure of 5 per cent was an improvement on that deduced from previous surveys (for example those conducted for Icotas by Hoverlloyd, British Rail, \&c.) which seemed to indicate a nonobservance of is per cent. However once again the evidence was inconclusive and stressed the requirement for a full traffic surveillance programme.

\section{Discipline}

The possibility of making the routes mandatory rather than recommended was discussed, but it was felt that the difficulties of enforcement would probably prove insuperable. It might be possible to write something into the Collision Regulations to encourage greater discipline, but the revised Regulations would not be at sea for five or six years and the problem was urgent. It was felt that every measure possible to encourage full observance of the recommended routes should be taken, including the better education of mariners in the ideas behind routing. The possibility of radar surveillance in congested areas like the Dover Strait should not, however, be overlooked.

\section{Improvements to the Scheme}

A hydrographic survey of the lower North Sea completed recently by the British and Netherlands Hydrographic departments, although it indicated alterations to the soundings which might create local problems, did not in the Committee's view call for any fundamental revision of the present routes.

The major problems in the Strait as seen by the Committee were the deepdraught route in the vicinity of the Sandettie bank and the width of the inshore zone along the English coast. Very deep-draught traffic would not in the foreseeable future exceed something like I per cent of the total in the Strait and should not be allowed to dominate it. On the other hand the feasibility of providing a route for deep-draught ships west of the Sandettié should, the Committee thought, be looked at immediately. They also believed that better use might be made of the available water by extending, widening and marking the inshore zone on the English side and providing for ships on recommended routes to use the passage between the Varne and the Ridge.

\section{The Trinity House Scheme}

The Committee considered the proposals of Trinity House and the Honourable Company of Master Mariners for reversing the direction of traffic flow in the Strait. They felt that, for many reasons, a much more compelling case must be made out for any radical change in a routing system than need be suggested for retaining it. Quite apart from the arguments, which the Committee could not as a whole accept, a change-over would, they believed, involve difficulties which they felt to be unacceptable. After $3 \frac{1}{2}$ years of routing there still seemed to be confusion in the minds of some Masters and a change-over could only exacerbate this situation.

Provision for the adjustment of routing schemes is made in Imco's Ships' Routeing and Traffic Separation Schemes, in which the internationally accepted principles of ship routing are now defined. However, in the Committee's view a radical alteration to a scheme already in operation should only be made after a full and objective investigation into its effectiveness, taking into account the pattern of traffic flow, collision statistics, the effect alterations may have on the ordered flow of traffic outside the scheme, and of course opinion at sea. 
The inquiry into the opinion of Masters and others conducted by Trinity House and the Honourable Company of Master Mariners did not, in the Committee's view, meet the requirements of an objective survey; in any event, no canvass of opinion could on its own be a sufficient basis for radical alterations to recommended routes.

The traffic situation in the Strait can now, the Committee felt, only be substantially improved as a result of far more information than is at present available; and this can only be obtained as the result of a properly conducted systematic traffic survey. Until this information is available, the present scheme must be supported and nothing done to erode the discipline which proper compliance with it involves.

\title{
Pilotage
}

Some consideration was given to the problem of pilotage in the area, since clearly the location of pilot stations will have a considerable effect on the pattern of traffic and on the ease with which recommended routes may be followed. It was suggested, for instance, that there could be some correlation between on the one hand the 'accident black spot' that has appeared recently in the southbound lane east of Folkestone and on the other the improvement of the situation off Dungeness, with the shift in I 968 of the pilot station from Dungeness to Folkestone. It is impossible without much more detailed information to comment on this suggestion. On the other hand it is clear that the siting of a pilot station is an important element in the successful operation of any traffic separation scheme.

London

4 February 1971
M. W. RicheY

Executive Secretary

\section{Collisions in the Dover Strait}

\author{
A. N. Black
}

IN the October Journal, p. $53^{8}$ and Table I on p. 539 , it is shown that the number of collisions per fog day (abbreviated below to $\mathrm{c} / \mathrm{fd}$ ) has fallen by some 20 per cent since routing was introduced in 1967 . It is not legitimate to assume without further argument that this is a case of cause and effect.

In particular it is noticeable, from the graph in the frontispiece to the October Journal, that the $\mathrm{c} / \mathrm{fd}$ showed a tendency to fall during the years preceding routing. Whatever the cause of this fall might be (e.g. more radar sets in use, variation in fog frequency, better simulator courses) it might well be unaffected by routing. If so one would expect the $\mathrm{c} / \mathrm{fd}$ to be lower in later years even if routing had no effect.

Statistical analysis shows that the apparent downward trend on $\mathrm{c} / \mathrm{fd}$ is not significant, so that one cannot be sure that it is a real effect. But the probability 